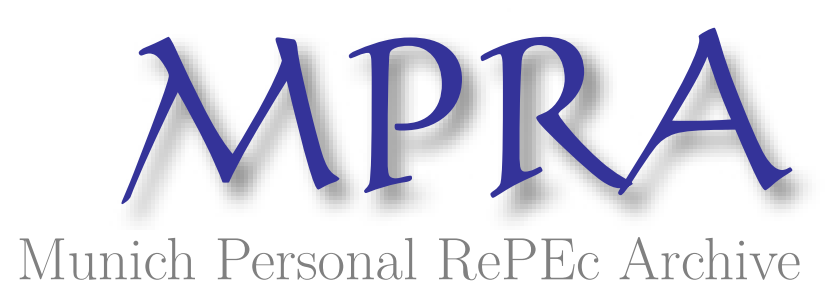

\title{
Endogenous growth, decline in social capital and expansion of market activities
}

Bartolini, Stefano and Bonatti, Luigi

University of Siena and University of Trento

May 2007

Online at https://mpra.ub.uni-muenchen.de/3341/

MPRA Paper No. 3341, posted 28 May 2007 UTC 


\title{
Stefano Bartolini ${ }^{\circ}$ and Luigi Bonatti*
}

\section{ENDOGENOUS GROWTH, DECLINE IN SOCIAL CAPITAL AND EXPANSION OF MARKET ACTIVITIES}

\begin{abstract}
We model in an endogenous growth set-up the hypotheses that the expansion of market activities weakens social capital formation, and that firms can invest in formal mechanisms of control and enforcement to substitute for social capital (trust, work ethics, honesty). The model shows that the economy tends to grow faster when it is relatively poorer in social capital and that perpetual growth can be consistent with the progressive erosion of social capital. These results may help reconciling Putnam's claim that social capital has declined in the U.S. with the satisfactory growth performance of the U.S. economy over the same period.
\end{abstract}

Keywords: Generalized trust, externalities, marketization, social assets.

JEL Classification numbers: O13, O41, Q20, Z13.

\footnotetext{
University of Siena, bartolinist@unisi.it

*University of Trento, luigi.bonatti@unibg.it
} 


\section{INTRODUCTION}

Consistently with a definition of social capital as those features of social organizations that facilitate coordination and cooperation (specifically, values and norms of reciprocity inhering in one's social networks), one should expect that members of communities with high stocks of social capital tend to be more able to costlessly monitor one another's behavior, reach informal understanding and agreements, enforce contracts, resolve disputes amicably. In such communities, the incidence of litigation, corruption, conflicts and crime should be low, transaction costs should be reduced, and market activities should be facilitated.

This claim that social capital is important for market efficiency is linked in this paper to the idea that the greatest danger to the social capital arises from the market itself. This idea has a long history and some authors went so far as to maintain that the decline of the values (honesty, business ethics, trust...) that prevent the spread of the opportunism generated by a market society will end up by destroying the latter (Hirsch, 1976; Hirschman, 1982). ${ }^{1}$ According to them, the progressive weakening of the cultural and ethical base of a market economy is a consequence of its evolution and success, since the individualistic and competitive values system connected with the expansion of a market economy is the greatest threat to the efficient functioning of markets. A complementary thesis is that, in a society that becomes more complex and differentiated, impersonal relations increasingly replace face-to-face interactions, thus undermining the possibility of founding economic transactions on interpersonal trust (see Hardin, 1998). Also Putnam (2000) links the marked decline in social capital that he documents to have occurred in the United States in the last

\footnotetext{
${ }^{1}$ Fukuyama (1995) fully embraces the idea that capitalism tends to erode social capital but offers an optimistic view of its ability to regenerate that capital. The perception that there is a conflict between a development strategy advocating a stronger role for social capital and an agenda emphasizing market incentives and material values is present also in the current policy debates (see, e.g., Heyer et al., 2002). In the same time, the idea that any development process brings destruction of social capital has been recently challenged by studies focusing on specific episodes and experiences (see, e.g., Miguel et al., 2006).
} 
decades to socio-economic transformations which one can consider by-products of the process of marketization. ${ }^{2}$ Indeed, he identifies some possible determinants of this decline in the rising female participation in the labor market, in the increase in geographical mobility, in "the replacement of the corner grocery by the supermarket" and in the "privatizing" or "individualizing" of the leisure time (mainly due to the TV and to the diffusion of other home-entertainment technologies). More in general, some have argued that, as income rises and the size of the middle class expands, many retreat from highly motivated social idealism and civic engagement to pursue personal objectives. ${ }^{3}$

However, some striking evidence presented by Putnam (2000) to support his claim that social trust has steadily declined in the US in the last decades, i.e. the evidence that documents the explosive increase in the society's expenditures in formal activities of social control and dispute resolution, ${ }^{4}$ is consistent with the hypothesis that the erosion of social capital stimulates the rapid growth of entire sectors of the economy, which are the sectors providing those services that economic agents use to protect themselves against increasing opportunistic and defiant behavior by others. The growth of these sectors is surely related to the long-term rise in the "transaction cost sector" that was illustrated by Wallis and North (1986) for the U.S. economy. ${ }^{5}$ Moreover, this

\footnotetext{
${ }^{2}$ The general thesis that social capital has declined in the United States, documented by Skocpol (1999) and Putnam (2000), was already presented by Putnam (1995), raising a critical debate. Some researchers (see, e.g., Ladd, 1996; Paxton, 1999) contested Putnam's conclusions. Subsequent studies tend to confirm the main Putnam's thesis (see, e.g., Costa and Kahn, 2003; Kolodinsky et al. , 2003; Keele, 2004).

${ }^{3}$ This point was suggested by a referee, who interprets this modification of attitudes and ideologies as a consequence of the evolution of the "shared mental models" that individuals construct to make sense of the world around them (see Denzau and North, 1994).

${ }^{4}$ Putnam (2000) emphasizes that during the 1980s spending on security rose rapidly as a share of U.S. GDP. Moreover, he observes that by 1995 America had 40\% more police and guards and 150\% more lawyers and judges than would have been projected in 1970, even given the growth of population and the economy (see Putnam, 2000, p. 146).

${ }^{5}$ Wallis and North (1986) estimated that the transaction cost sector (private plus public) amounted to $26.1 \%$ of U.S. GDP in 1870 and to $54.7 \%$ in 1970.
} 
growth--which is paralleled by the decline in peer monitoring and informal sanctioning--can be considered a symptom of the increasingly explicit nature of norm enforcement that proceeds with modernization (see Bowles and Jayadev, 2006). ${ }^{6}$

Summarizing, the progressive "marketization" of social life, namely the process through which market relations become more pervasive, contributes to the diffusion of values, attitudes and behavior that do not favor the formation of social capital. In its turn, the decline in social capital induces the economic agents to use more market services as substitutes for the diminished flow of services provided by it. ${ }^{7}$ The resources devoted to this use are subtracted from other productive uses, but in the same time they permit to counterbalance the negative effect of a lower social capital on the productivity of inputs such as labor, human and physical capital.

It should be clear from the previous discussion that analyzing the impact of a decline in social capital on economic growth one must consider not only its depressing consequences for factor productivity but also its stimulus to the expansion of market activities. One should also account for the self-feeding process whereby this expansion has a further negative effect on the formation of social capital. The original model presented in this paper contains all these features. Furthermore, taking for granted that there have been a decline in the U.S. social capital, it may help explaining why--especially in the 1990s--this fall in social capital does not appear to have been paralleled in the United States by a disappointing growth performance. Indeed, this stylized fact seems at odds with Putnam's statement that social capital produces "aggregate economic growth" (Putnam, 2000, p.322-3). Also Durlauf and Fafchamps (2004) stress this point: "Putnam (2000), focusing on the U.S. experience since the 1950s, argues that social capital, defined as membership in formal and informal clubs, has declined monotonically since the 1950s. This is true for all states, all decades and all measures of social capital. However, he finds no relationship between the speed

\footnotetext{
${ }^{6}$ Bowles and Jayadev (2006) document that supervisors and guards (police, corrections officials and security personnel) were $17.9 \%$ of the U.S. labor force in 2002 , while the corresponding figure was $10.8 \%$ in 1966 .

${ }^{7}$ The expenditures for these market services can be interpreted as defensive expenditures.
} 
of the decline of social capital and economic performance across U.S. states or across time periods. Further, the relationship between social capital and socioeconomic outcomes is even harder to characterize when one looks at subperiods. For example, the 1990's were a period of rapid economic growth in the U.S. yet it is also a period of rapid decline in social capital, at least based on the sorts of measures he uses. To be clear, Putnam does attempt to associate higher social capital with better socioeconomic outcomes, our point is that the relationship between the two for the United States is even at first glance relatively complicated" (p. 12). ${ }^{8}$ Moreover, both Durlauf (2002b) and Bovenberg (2003) complained about the absence of theoretical models that define precisely the mechanisms through which endogenous and exogenous variables interact and codetermine the time profile of social capital and of other indicators of economic performance. ${ }^{9}$

We contribute to fill this void by presenting an endogenous growth model that links social capital formation to the decisions by which economic agents determine their working time, accumulate human \& physical capital and may substitute market services for the services provided by social capital. The model combines the idea that knowledge and productivity gains are achieved by each firm through (human \& physical) capital utilization and spill over across all firms and the idea that the expansion of market production by each firm has negative externalities on the

\footnotetext{
${ }^{8}$ The existence of a systematic relationship between social capital and economic performance across U.S. states is questioned by Casey and Christ (2002): their regression analysis incorporates state-level measures of physical and human capital, showing that connection between social capital index measures and output indicators is either negative or statistically insignificant. In contrast, Rupasingha et al. (2002) find evidence that higher levels of social capital— together with other economic and social factors-have systematic and positive effects on growth rates among U.S. counties. In general, cross-sectional studies appear to show the existence of a positive relation between social capital (generally measured in terms of generalized trust and associational activity) and economic growth (Knack and Keefer, 1997; La Porta et al., 1997; Zak and Knack, 2001; Beugelsdijk et al., 2004; Beugelsdijk and Schaik, 2005). However, these studies have been subject to severe criticism (Durlauf, 2002a; Durlauf and Fafchamps, 2004).

${ }^{9}$ A recent theoretical model focusing on the relation between social capital and economic growth is Beugelsdijk and Smulders (2004), which accounts for the possible trade off between social capital formation and GDP growth.
} 
formation of social capital. ${ }^{10}$ Within this framework, it is shown that perpetual growth can be possible even if social capital-which enters the aggregate production function--is progressively eroded, and that in the long run an economy that grows faster tends to be relatively poorer in social capital and to exhibit a higher level of market work. Hence, our model can reconcile an observed decline in social capital with a satisfactory GDP growth in the long run. Moreover, it accounts for the possibility that a decline in social capital is accompanied by a rise in hours of market work per household, which is consistent with the fact that a documented increase in market work per adult has occurred in the United States starting from the early 1970s (see, e.g., Freeman and Schettkat, 2005), namely in a period in which--according to Putnam--U.S. social capital has declined.

The paper is organized as follows: section 2 presents the model, section 3 characterizes the equilibrium trajectories of the economy and section 4 concludes.

\section{THE MODEL}

We consider an economy in discrete time with an infinite time horizon. In this economy there are firms and households.

\subsection{The firms}

For simplicity and without loss of generality, it is assumed that there is a fixed and large number (normalized to be one) of perfectly competitive firms that are identical and produce the single product existing in this economy. The representative firm produces its output $\mathrm{Y}_{\mathrm{t}}$ according to the technology

\footnotetext{
${ }^{10}$ Our model follows the "social" approach to social capital, according to which social capital exists within a community and has to be considered as the (unintended) by-product of a large number of individual choices (see Bowles and Gintis, 2002; Routledge and von Amsbergh, 2003).
} 


$$
\mathrm{Y}_{\mathrm{t}}=\mathrm{A}_{\mathrm{t}} \mathrm{L}_{\mathrm{t}}^{\alpha} \mathrm{K}_{\mathrm{t}}^{\beta} \mathrm{F}_{\mathrm{t}}^{1-\alpha-\beta}, \alpha>0, \beta>0, \alpha+\beta<1,
$$

where $A_{t}$ denotes the state of technology in $t, L_{t}$ are the units of labor employed by the firm in $t, K_{t}$ is the amount of capital rent by the firm in $t$, and $F_{t}$ is a measure of the level of protection from opportunism, dishonesty and confiscation enjoyed by the firm in $\mathrm{t}$. Note that $\mathrm{K}_{\mathrm{t}}$ "should be interpreted broadly so as to include human as well as physical capital" (Aghion and Howitt, 1998, p. 11).

It is assumed that $A_{t}$ is a positive function of the stock of human \& physical capital existing in the economy: $A_{t}=K_{t}^{\alpha}$ (consistently with this formal set-up, one can interpret technological progress as labor augmenting). This assumption combines the idea that learning-by-doing works through each firm's (human \& physical) capital utilization and the idea that knowledge and productivity gains spill over instantly across all firms (see Barro and Sala-i-Martin, 1995). ${ }^{11}$ Therefore, in accordance with Frankel (1962), it is supposed that although $A_{t}$ is endogenous to the economy, each firm takes it as given, since a single agent's investment decisions have only a negligible effect on the aggregate stock of human \& physical capital.

The variable $\mathrm{F}_{\mathrm{t}}$ depends on the stock of social capital existing in the economy in period $\mathrm{t}, \mathrm{S}_{\mathrm{t}}$, and on the amount of resources devoted by the firm to the protection from opportunistic and defiant behaviors, to the execution of contracts, and to the defense of property rights in $t, X_{t}:{ }^{12}$

\footnotetext{
${ }^{11}$ Barro and Sala-i-Martin (1995) point out that the absence of diminishing returns to capital becomes more realistic if we think of $\mathrm{K}_{\mathrm{t}}$ in a broad sense to include both physical and human capital.

${ }^{12}$ The model is also open to the interpretation of $\mathrm{S}_{\mathrm{t}}$ as an environmental asset. Consistently with this interpretation, one may suppose that an increasing amount of current output has to be used to preserve factor productivity as environmental quality worsens (for instance, more fertilizers and irrigation are needed to preserve land fertility as the global climate becomes less favorable to farming, or more medical care is needed to preserve labor productivity as air quality deteriorates).
} 


$$
\mathrm{F}_{\mathrm{t}}=\left(\mathrm{S}_{\mathrm{t}}^{1 / \zeta}+\mathrm{X}_{\mathrm{t}}^{1 / \zeta}\right)^{\zeta}, 0<\zeta \leq 1
$$

One may interpret $\mathrm{S}_{\mathrm{t}}$ as a measure of the level of trust, work ethics and honesty existing in the society at time t. Hence, (2) captures a situation in which a decline in peer monitoring and informal sanctioning can be counterbalanced by an increase in the amount of resources invested in formal mechanisms of control and enforcement. In other words, (2) applies to those agency problems that emerge in contractual relationships and are exacerbated by a fall in mutual trust and shared values. ${ }^{13}$ However, (2) generalizes to other situations--such as those in which economic agents are exposed to the risk of crime or confiscation - that cannot be analyzed in terms of principal-agent relationships. Note also in (1) and (2) that a higher level of social capital raises total factor productivity and that $X_{t}$ is a substitute for $S_{t}$, where $\zeta=1$ applies to the case in which $X_{t}$ and $S_{t}$ are perfect substitutes. Therefore, we admit the possibility that a private good can be used as a substitute for a common, namely for a form of capital that cannot be privately appropriated and accumulated.

Since $X_{t}$ is the amount of $Y_{t}$ used as intermediate service by the firm in $t,{ }^{14}$ the value added generated by each firm is given by

$$
\mathrm{GDP}_{\mathrm{t}}=\mathrm{Y}_{\mathrm{t}}-\mathrm{X}_{\mathrm{t}}
$$

where $Y_{t}$ is the numeraire of the system and its price is set to be one.

In each $t$, the representative firm chooses $X_{t}, L_{t}$ and $K_{t}$ in order to maximize its profits, which are given by

$$
\pi_{\mathrm{t}}=\mathrm{Y}_{\mathrm{t}}-\mathrm{X}_{\mathrm{t}}-\mathrm{W}_{\mathrm{t}} \mathrm{L}_{\mathrm{t}}-\mathrm{R}_{\mathrm{t}} \mathrm{K}_{\mathrm{t}}
$$

\footnotetext{
${ }^{13}$ Zak and Knack (2001) presents a principal-agent model in which, when the social and institutional environment is characterized by low trust, principals spend more resources to monitor their agents, thus reducing investment and growth.

${ }^{14}$ It is immaterial in this context if the firm buys $X_{t}$ from some other firm or if it employs as intermediate good a portion of its own output.
} 
where $\mathrm{R}_{\mathrm{t}}$ is the capital rental rate and $\mathrm{W}_{\mathrm{t}}$ is the wage rate.

\subsection{The law of motion of the social capital}

Across the social sciences, a recurring hypothesis is that the expansion of market activity may undermine the society's ability to regenerate its social assets. According to this thesis, the level of generalized trust, civic engagement, public ethics and personal honesty may suffer because of the increased "marketization" of social life, which brings about as a by-product the diffusion of attitudes and values like greed, cynicism and opportunism. Obviously, this does not imply that no social capital can be accumulated as an intended consequence of some market activity: for instance, one may argue that social capital can also be built in the commercial workplace, since most people socialize while working (see Maskell, 2000). However, it is often the case that market activities subtract time and efforts to other activities that are more productive in terms of social capital formation. ${ }^{15}$ Therefore, we maintain that the net effect of the increased marketization on social capital formation is negative, and we use the volume of goods and services that are produced for monetized exchange by profit-maximizing firms as a proxy of the degree of marketization. It is also assumed that the larger this volume, the higher has to be the stock of social capital in order to offset the detrimental effect of this greater degree of marketization on the level of generalized trust, civic engagement, public ethics and personal honesty. In other words, the stock of social capital declines whenever the ratio $S_{t} / Y_{t}$ tends to fall below a critical thresholds. Hence, we may summarize this discussion by modeling the evolution in time of the stock of social capital as follows:

\footnotetext{
${ }^{15}$ There are models emphasizing the existence of a trade-off between using time to build social capital and devoting it to market activities. Chou (2002) proposes a growth model in which agents face a trade-off between devoting resources to final goods production, to human capital accumulation and to building social capital. Beugelsdijk and Smulders (2004) assume that the participation in intercommunity networks ("bridging" social capital) enhances growth by reducing the incentives for rent seeking and cheating, and it depresses growth by reducing the time devoted by people to market activities.
} 


$$
\frac{\mathrm{S}_{\mathrm{t}+1}-\mathrm{S}_{\mathrm{t}}}{\mathrm{S}_{\mathrm{t}}}=\rho\left(\frac{\mathrm{S}_{\mathrm{t}}}{\mathrm{Y}_{\mathrm{t}}}-\xi\right), \rho>0, \xi>0, \mathrm{~S}_{0} \text { given. }
$$

It is worth to emphasize that $\mathrm{Y}_{\mathrm{t}}$ is the aggregate market output in period $\mathrm{t}$ : a single firm can take the evolution of $\mathrm{S}_{\mathrm{t}}$ as given since it has only a negligible effect on it. ${ }^{16}$

\subsection{The households}

For simplicity and without loss of generality, it is assumed that the population is constant and that each household contains one adult, working member of the current generation. Thus, there is a fixed and large number (normalized to be one) of identical adults who take account of the welfare and resources of their actual and prospective descendants. Following Barro and Sala-i-Martin (1995) we model this intergenerational interaction by imagining that the current generation maximizes utility and incorporates a budget constraint over an infinite future. That is, although individuals have finite lives, we consider immortal extended families ("dynasties"). ${ }^{17}$ Finally, we assume that agents' expectations are rational, in the sense that they are consistent with the real processes followed by the relevant variables. In this framework, in which there is no source of random disturbances, this implies perfect foresight.

In each period t, the utility of the representative household is an increasing function of consumption and leisure:

$$
\mathrm{U}_{\mathrm{t}}=\ln \left(\mathrm{C}_{\mathrm{t}}\right)+\gamma \ln \left(1-\mathrm{L}_{\mathrm{t}}\right), \gamma>0, \mathrm{~L}_{\mathrm{t}} \leq 1
$$

where $\mathrm{C}_{\mathrm{t}}$ is consumption in $\mathrm{t}$ and $1-\mathrm{L}_{\mathrm{t}}$ is the time devoted to leisure by the representative household (the total amount of time available to the household in each $\mathrm{t}$ is normalized to be one).

\footnotetext{
${ }^{16}$ If one interprets $\mathrm{S}_{\mathrm{t}}$ as an environmental asset affecting productivity, equation (5) may model the negative effect of aggregate production on the nature's absorption capacity, namely on its capacity of preserving a certain level of environmental quality.

${ }^{17}$ As Barro and Sala-i-Martin (1995, p. 60) point out, "this setting is appropriate if altruistic parents provide transfers to their children, who give in turn to their children, and so on. The immortal family corresponds to finite-lived individuals who are connected via a pattern of operative intergenerational transfers that are based on altruism”.
} 
The period budget constraint of the representative household is the following:

$$
\mathrm{K}_{\mathrm{t}+1}+\mathrm{C}_{\mathrm{t}}=\mathrm{K}_{\mathrm{t}}(1-\delta)+\pi_{\mathrm{t}}+\mathrm{R}_{\mathrm{t}} \mathrm{K}_{\mathrm{t}}+\mathrm{W}_{\mathrm{t}} \mathrm{L}_{\mathrm{t}}, 0<\delta<1, \mathrm{~K}_{0} \text { given, }
$$

where $\delta$ is a parameter capturing (human \& physical) capital depreciation. It is assumed that each household is entitled to receive an equal share of the firms' profits.

The problem of the representative household amounts to choose $\left\{\mathrm{K}_{\mathrm{t}+1}\right\}_{0}^{\infty},\left\{\mathrm{C}_{\mathrm{t}}\right\}_{0}^{\infty}$ and $\left\{\mathrm{L}_{\mathrm{t}}\right\}_{0}^{\infty}$ in order to maximize

$$
\sum_{\mathrm{t}=0}^{\infty} \theta^{\mathrm{t}} \mathrm{U}_{\mathrm{t}}, 0<\theta<1,
$$

subject to (7), where $\theta$ is a time-preference parameter.

\subsection{Market-clearing conditions}

Equilibrium in the market for the product implies

$$
\mathrm{K}_{\mathrm{t}+1}+\mathrm{C}_{\mathrm{t}}=\mathrm{K}_{\mathrm{t}}(1-\delta)+\mathrm{Y}_{\mathrm{t}}-\mathrm{X}_{\mathrm{t}}
$$

Equilibrium in the markets for labor and for human \& physical capital implies, respectively

$$
\mathrm{L}_{\mathrm{t}}^{\mathrm{d}}=\mathrm{L}_{\mathrm{t}}^{\mathrm{s}}
$$

and

$$
\mathrm{K}_{\mathrm{t}}^{\mathrm{d}}=\mathrm{K}_{\mathrm{t}}^{\mathrm{s}}
$$

\section{THE EQUILIBRIUM DYNAMICS OF THE ECONOMY}

\subsection{Characterization of general equilibrium paths and balanced growth paths}

By solving the optimization problem of firms and households, one obtains the system of

difference equations in $V_{t} \equiv \frac{X_{t}}{K_{t}}$ and $Q_{t} \equiv \frac{S_{t}}{X_{t}}$ that governs the evolution of the economy along an equilibrium trajectory (see the Appendix): 


$$
\begin{aligned}
& \Omega\left(\mathrm{Q}_{\mathrm{t}+1}, \mathrm{~V}_{\mathrm{t}+1}, \mathrm{Q}_{\mathrm{t}}, \mathrm{V}_{\mathrm{t}}\right)=\frac{\mathrm{Q}_{\mathrm{t}+1} \mathrm{~V}_{\mathrm{t}+1}\left[1+\omega\left(\mathrm{Q}_{\mathrm{t}}, \mathrm{V}_{\mathrm{t}}\right)\right]}{\mathrm{V}_{\mathrm{t}}}-\mathrm{Q}_{\mathrm{t}}-\rho \mathrm{Q}_{\mathrm{t}}\left[\frac{\mathrm{Q}_{\mathrm{t}}(1-\alpha-\beta)}{\left(\mathrm{Q}_{\mathrm{t}}^{1 / \zeta}+1\right)}-\xi\right]=0 \\
& \Theta\left(\mathrm{Q}_{\mathrm{t}+1}, \mathrm{~V}_{\mathrm{t}+1}, \mathrm{Q}_{\mathrm{t}}, \mathrm{V}_{\mathrm{t}}\right)=\mathrm{V}_{\mathrm{t}+1}\left(\mathrm{Q}_{\mathrm{t}+1}^{1 / \zeta}+1\right)\left[1+\omega\left(\mathrm{Q}_{\mathrm{t}}, \mathrm{V}_{\mathrm{t}}\right)\right]\left[\left[\frac{(1-\alpha-\beta) \mathrm{V}_{\mathrm{t}+1}^{-\alpha-\beta}}{\left(\mathrm{Q}_{\mathrm{t}+1}^{1 / \zeta}+1\right)^{1-\zeta(1-\alpha-\beta)}}\right]^{1 / \alpha}-1\right\}- \\
& -\mathrm{V}_{\mathrm{t}}\left(\mathrm{Q}_{\mathrm{t}}^{1 / \zeta}+1\right)\left\{\left[\frac{(1-\alpha-\beta) \mathrm{V}_{\mathrm{t}}^{-\alpha-\beta}}{\left(\mathrm{Q}_{\mathrm{t}}^{1 / \zeta}+1\right)^{1-\zeta(1-\alpha-\beta)}}\right]^{1 / \alpha}-1\right\} \theta\left[1-\delta+\frac{\beta \mathrm{V}_{\mathrm{t}+1}\left(\mathrm{Q}_{\mathrm{t}+1}^{1 / \zeta}+1\right)}{1-\alpha-\beta}\right]=0,
\end{aligned}
$$

where

$$
\mathrm{h}_{\mathrm{t}} \equiv \frac{\mathrm{K}_{\mathrm{t}+1}-\mathrm{K}_{\mathrm{t}}}{\mathrm{K}_{\mathrm{t}}}=\omega\left(\mathrm{Q}_{\mathrm{t}}, \mathrm{V}_{\mathrm{t}}\right)=\frac{\mathrm{V}_{\mathrm{t}}\left(\mathrm{Q}_{\mathrm{t}}^{1 / \zeta}+1\right)}{1-\alpha-\beta}\left\{1-\frac{\alpha}{\gamma}\left[\frac{(1-\alpha-\beta) \mathrm{V}_{\mathrm{t}}^{-\alpha-\beta}}{\left(\mathrm{Q}_{\mathrm{t}}^{1 / \zeta}+1\right)^{1-\zeta(1-\alpha-\beta)}}\right]^{1 / \alpha}+\frac{\alpha}{\gamma}\right\}-\delta-\mathrm{V}_{\mathrm{t}} \cdot
$$

Together with (12)-(14), an equilibrium path must satisfy the transversality condition (see the Appendix)

$$
\lim _{t \rightarrow \infty} \frac{\gamma(1-\alpha-\beta) \theta^{t}}{V_{t}\left(Q_{t}^{1 / \zeta}+1\right) \alpha}\left\{\left[\frac{(1-\alpha-\beta) \mathrm{V}_{t}^{-\alpha-\beta}}{\left(Q_{t}^{1 / \zeta}+1\right)^{1-\zeta(1-\alpha-\beta)}}\right]^{1 / \alpha}-1\right\}^{-1}=0
$$

A balanced growth path (BGP) can be characterized by setting $\mathrm{Q}_{\mathrm{t}+1}=\mathrm{Q}_{\mathrm{t}}=\mathrm{Q}$ and $\mathrm{V}_{\mathrm{t}+1}=\mathrm{V}_{\mathrm{t}}=\mathrm{V}$ in the system (12)-(13). There may exist a multiplicity of BGPs. Assuming that the parameter values are such that multiple BGPs exist (see the Appendix), the following proposition holds: 
Proposition 1. Per capita GDP grows faster along the BGP characterized by a lower Q, i.e., by a lower ratio between social capital and amount of resources invested in formal mechanisms of control and enforcement.

Proof: See the Appendix.

Proposition 1 states that the economy is relatively poorer in social capital along the long-run equilibrium trajectory characterized by the higher rate of economic growth. This reflects the selffeeding process whereby a fast growing market production induces the firms to rapidly increase their expenditures in formal mechanisms of control and enforcement in response to the relative decline in social capital brought about by this fast growth.

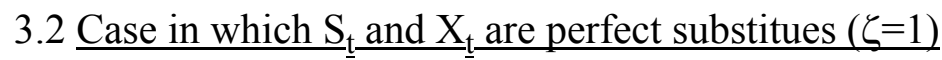

In this special case, the system governing the equilibrium path of the economy can also be

expressed in terms of $\mathrm{L}_{t}$ and $\mathrm{D}_{\mathrm{t}} \equiv \frac{\mathrm{S}_{\mathrm{t}}}{\mathrm{K}_{\mathrm{t}}}$, and one can show that there may exist at most two BGPs, $\left(\mathrm{L}^{\circ}, \mathrm{D}^{\circ}\right)$ and $\left(\mathrm{L}^{*}, \mathrm{D}^{*}\right)$, where $\mathrm{L}^{\circ}>\mathrm{L}^{*}$ and $\mathrm{D}^{\circ}=0<\mathrm{D}^{*}$ (see the Appendix). Assuming that both these BGP exist (see the Appendix), one can prove the following proposition:

Proposition 2. Per capita GDP grows faster along the BGP characterized by more time worked per household and by a lower social capital-to-human \& physical capital ratio.

Proof: One can check that $0<\mathrm{h}^{\circ}=\mu\left(\mathrm{L}^{\circ}, \mathrm{D}^{\circ}\right)>\mathrm{h}^{*}=\mu\left(\mathrm{L}^{*}, \mathrm{D}^{*}\right)\left(\right.$ entailing $\left.\mathrm{g}^{\circ}>\mathrm{g}^{*}, \mathrm{~g}_{\mathrm{t}} \equiv \frac{\mathrm{GDP}_{\mathrm{t}+1}-\mathrm{GDP}_{\mathrm{t}}}{\mathrm{GDP}_{\mathrm{t}}}\right)$ (see the Appendix).

Proposition 2 reinforces Proposition 1 in emphasizing that the economy tends to grow faster when it is relatively poorer in social capital: the rate of GDP growth is higher along the BGP characterized by a lower ratio between social capital and human \& physical capital. Moreover, it states that along this BGP the households devote more time to market activities. As a matter of fact, the relative decline in social capital associated with a more rapid expansion of market activities is accompanied by the households' tendency to accumulate more human \& physical capital and to 
supply more labor. It is worth to notice that a lower capital-to-human \& physical capital ratio depresses profits per unit of capital, since firms have to incur an increasing cost to offset the effects of the relative decline in social capital on their inputs' productivity.

As $\zeta=1$, one can also prove the following proposition:

Proposition 3. The cumulative process that is ignited when the stock of social capital is low relatively to the volume of market activities leads the economy to converge asymptotically to $\left(\mathrm{L}^{\circ}, \mathrm{D}^{\circ}\right)$

Proof: By linearizing the system governing the equilibrium path of the economy in a neighborhood of $\left(\mathrm{L}^{\circ}, \mathrm{D}^{\circ}\right)$ and $\left(\mathrm{L}^{*}, \mathrm{D}^{*}\right)$, one can check that $\left(\mathrm{L}^{\circ}, \mathrm{D}^{\circ}\right)$ is saddle-path stable, while $\left(\mathrm{L}^{*}, \mathrm{D}^{*}\right)$ is unstable (see the Appendix). Hence, it is necessarily the case that if $\mathrm{D}_{0} \in\left(\mathrm{D}^{\circ}, \mathrm{D}^{\circ}+\varepsilon\right), \varepsilon>0$, the social capitalhuman \& physical capital ratio tends to approach $\mathrm{D}^{\circ}=0$ as $\mathrm{t} \rightarrow \infty$.

Finally, one can focus on the transition path of this economy by studying the linearized system that governs the saddle path converging to $\left(\mathrm{L}^{\circ}, \mathrm{D}^{\circ}\right)$ in the case in which $\zeta=1$ :

$$
\begin{gathered}
\mathrm{D}_{\mathrm{t}}=\mathrm{e}_{11} \mathrm{D}_{0} \chi_{1}^{\mathrm{t}}, 0<\chi_{1}<1, \\
\mathrm{~L}_{\mathrm{t}}-\mathrm{L}^{\circ}=\mathrm{e}_{21} \mathrm{D}_{0} \chi_{1}^{\mathrm{t}},
\end{gathered}
$$

where $\left[\begin{array}{l}e_{11} \\ e_{21}\end{array}\right]$ are the characteristic vectors associated with the stable root $\chi_{1}$. The system (16)-(17) is such that the following proposition holds:

Proposition 4. Along the path converging asymptotically to $\left(\mathrm{L}^{\circ}, \mathrm{D}^{\circ}\right)$, the social capital-human \& physical capital ratio decreases monotonically and the time worked per household increases monotonically.

Proof: One can check that $\mathrm{e}_{11}=1$ and $\mathrm{e}_{21}<0$ (see the Appendix).

Proposition 4 establishes the negative relation linking the social capital-human $\&$ physical capital ratio and the households' working time along an equilibrium trajectory converging asymptotically to the BGP: as time passes, $\mathrm{D}_{\mathrm{t}}$ tends to fall while $\mathrm{L}_{\mathrm{t}}$ tends to increase approaching 
asymptotically its long-run equilibrium value. This result is consistent with the negative correlation that seems to emerge in the last decades in the United States between some social capital measures and market work per capita. ${ }^{18}$

A corollary of Proposition 4 is the following proposition:

Proposition 5. Perpetual economic growth can be consistent with the progressive erosion of social capital.

Proof: By considering Proposition 4, and equations (5) and (12), one can easily verify that along the path converging to $\left(\mathrm{L}^{\circ}, \mathrm{D}^{\circ}\right)$ the stock of social capital is asymptotically depleted. In addition, numerical examples show that one may have $\mathrm{g}^{\circ}=\mathrm{h}^{\circ}=\mu\left(\mathrm{L}^{\circ}, \mathrm{D}^{\circ}\right)>0$ (see the Appendix).

It is apparent that the content of Proposition 5, namely the fact that unbounded growth can occur in spite of the asymptotic depletion of social capital, relies on the possibility of substituting market services for the services provided by the stock of social capital. In the course of this process of substitution, costly formal mechanisms of control and enforcement gradually replace peer monitoring and informal sanctioning, without impeding unbounded growth. ${ }^{19}$

\footnotetext{
${ }^{18}$ As evidence supporting the existence of this negative correlation, one can invoke the fact that market work per capita has increased in the United States during the years in which Putnam and others document a fall in social capital. Moreover, a negative relation between some indicators of social capital and some measures of market work emerges in specific studies. Costa and Kahn (2003) present evidence showing that the rise in female labor force participation that has taken place since the 1960 s is an important determinant of the decline in the U.S. social capital. Keele (2004) finds that the increase in the hours worked per capita and the larger number of women in the labor force have a negative effect on the U.S. levels of civic participation and interpersonal trust. Bartolini and Bilancini (2006) show that individuals working a larger number of hours do not exhibit higher levels of interpersonal trust.

19 We accept the idea that conformity to the behaviors prescribed by social organizations may be secured by a combination of materialistic incentives, coercion, conventions, social sanctions (informal rules) and internalized norms which make conformity a best response for the members of a group (see Bowles and Jayadev, 2006). Therefore, we do not emphasize an interpretation of the progressive erosion of social capital in advanced societies as the process whereby self-interest gradually replaces trust as the main inspiration of individual behavior in social organizations, but rather as
} 


\section{CONCLUSIONS}

In this paper we have insisted on an interpretation of social capital as a resource connected with group membership and social networks (Bourdieu, 1986) which tends to deteriorate as market activities become more pervasive. The deterioration of this resource can be interpreted as a decline in social cohesion and general trust that forces economic agents to raise their expenditure aimed at self-protecting from increased opportunism and defiant behavior. To shed light on the dynamics of an economy where social capital has these characteristics, we have augmented a Solow-Ramsey growth model by including: i) social capital enhancing factor productivity, ii) negative externalities affecting social capital formation and increasing with the level of market activity, iii) the possibility for economic agents to substitute market services for social capital, iv) positive externalities affecting total factor productivity and increasing with the aggregate stock of physical capital, and v) a labor-leisure choice.

Within this framework, the economy may have multiple balanced growth paths (BGPs) and per capita GDP grows faster along the BGP characterized by a lower ratio between social capital and amount of resources invested in formal mechanisms of control and enforcement. In the special case in which market services are perfect substitutes for the services provided by social capital, it is shown that i) the balanced growth path along which per capita GDP grows faster exhibits the lower ratio between social capital and physical capital, ii) the economy converges asymptotically to the balanced growth path along which per capita GDP grows faster, the households devote more time to market activities and the social capital to physical capital ratio is lower, iii) along the transition trajectory converging to the balanced growth path the social capital-physical capital ratio decreases monotonically and the time worked per household increases monotonically, and iv) perpetual growth can be consistent with the progressive erosion of social capital.

the process whereby social sanctions and internalized norms gradually lose importance as motivations for inducing individuals to comply with the behaviors prescribed by institutions and organizations. 
The model presented here is consistent with the view that capitalism tends to erode the socio-cultural sediment on which it rests, but it does not share the view that this erosion imperils the growth prospects of the economy. In any case, we need systematic empirical evidence in order to assess how important are the impact of the expansion of market activities on social capital formation and the effects of the decline in social capital on the demand for market services that can substitute for it. Moreover, there are other elements of the relationship between social capital and economic growth that need to be clarified. In particular, future research should address the complex link connecting education and social capital and their joint impact on the growth process. Indeed, the existing literature has focused separately on various aspects of this connection, but without providing a formal framework for a unifying analysis of it. $^{20}$ Finally, the emphasis on the relationship linking the education system to the society's endowment of social capital naturally raises the question of the interaction between social capital and government institutions and policies in affecting growth. Again, the necessity of further research derives from the fact that the existing literature has not yet formally treated this complex issue. ${ }^{21}$

\footnotetext{
${ }^{20}$ Among the issues treated by the existing literature there are the following: the alternative between devoting time to the acquisition of cognitive skills or to the formation of social capital (Piazza-Georgi, 2002), the promotion of competitive motivations or cooperative attitudes among the young people attending schools, the role of social capital in facilitating the accumulation of human capital and in increasing its productivity (Coleman, 1988; Chou, 2002; Bjørnskov, 2004), the impact of schooling and the influence of human capital on the socialization process and on the formation of social capital (Bowles and Gintis, 1976; Schneider et al., 1997).

${ }^{21}$ A critical assessment of the theory concerning the relationship between government institutions and policies on one side and social capital on the other side should start from the commonly accepted conclusion "that centralised states destroy the social cohesion of traditional communities, undermine cooperation, and destroy trust among individuals" (Levi, 1998, pp. 81-82). In the same time, states are supposed to reduce the need for individuals to trust each other by providing effective monitoring and enforcement. In other words, according to this classical viewpoint, state coercion
} 


\section{Appendix}

\section{Derivation (12)-(15)}

One can solve the firms' problem by maximizing (4) with respect to $\mathrm{X}_{\mathrm{t}}, \mathrm{L}_{\mathrm{t}}$, and $\mathrm{K}_{\mathrm{t}}$, thus obtaining:

$$
\begin{gathered}
\mathrm{L}_{\mathrm{t}}=\left[\mathrm{X}_{\mathrm{t}}^{\frac{\zeta-1}{\zeta}} \mathrm{K}_{\mathrm{t}}^{-\alpha-\beta}\left(\mathrm{S}_{\mathrm{t}}^{\frac{1}{\zeta}}+\mathrm{X}_{\mathrm{t}}^{\frac{1}{\zeta}}\right)^{1-\zeta(1-\alpha-\beta)}(1-\alpha-\beta)^{-1}\right]^{\frac{1}{\alpha}}, \\
\mathrm{W}_{\mathrm{t}}=\alpha\left[\mathrm{K}_{\mathrm{t}}^{\alpha+\beta}\left(\mathrm{S}_{\mathrm{t}}^{\frac{1}{\zeta}}+\mathrm{X}_{\mathrm{t}}^{\frac{1}{\zeta}}\right)^{\zeta(1-\alpha-\beta)-1+\alpha}(1-\alpha-\beta)^{1-\alpha} \mathrm{X}_{\mathrm{t}}^{\frac{(1-\zeta)(1-\alpha)}{\zeta}}\right]^{\frac{1}{\alpha}}, \\
\mathrm{R}_{\mathrm{t}}=\beta\left(\mathrm{S}_{\mathrm{t}}^{\frac{1}{\zeta}}+\mathrm{X}_{\mathrm{t}}^{\frac{1}{\zeta}}\right)\left[\mathrm{K}_{\mathrm{t}}(1-\alpha-\beta) \mathrm{X}_{\mathrm{t}}^{\frac{1-\zeta}{\zeta}}\right]^{-1} .
\end{gathered}
$$

Given (1)-(4) and (A1)-(A3), one has:

$$
\begin{gathered}
\pi_{\mathrm{t}}=\mathrm{S}_{\mathrm{t}}^{\frac{1}{\zeta}} \mathrm{X}_{\mathrm{t}}^{\frac{\zeta-1}{\zeta}} \\
\mathrm{Y}_{\mathrm{t}}=\left(\mathrm{S}_{\mathrm{t}}^{\frac{1}{\zeta}}+\mathrm{X}_{\mathrm{t}}^{\frac{1}{\zeta}}\right)\left[(1-\alpha-\beta) \mathrm{X}_{\mathrm{t}}^{\frac{1-\zeta}{\zeta}}\right]^{-1}, \\
\operatorname{GDP}_{\mathrm{t}}=\left(\mathrm{S}_{\mathrm{t}}^{\frac{1}{\zeta}}+\mathrm{X}_{\mathrm{t}}^{\frac{1}{\zeta}}\right)\left[(1-\alpha-\beta) \mathrm{X}_{\mathrm{t}}^{\frac{1-\zeta}{\zeta}}\right]^{-1}-\mathrm{X}_{\mathrm{t}}
\end{gathered}
$$

Notice that firms' profits depend positively on social capital. This reflects the fact that a higher stock of social capital reduces the need for firms to devote resources to formal mechanisms of control and enforcement.

By using (5) and (A5), one can derive (12).

Moreover, one can solve the households' problem by maximizing

$$
\sum_{i=0}^{\infty} \theta^{i}\left\{\ln \left(C_{t+i}\right)+\gamma \ln \left(1-L_{t+i}\right)+\lambda_{t+i}\left[(1-\delta) K_{t+i}+\pi_{t+i}+W_{t+i} L_{t+i}+R_{t+i} K_{t+i}-C_{t+i}-K_{t+i+1}\right]\right\} \text { with respect to } C_{t}, L_{t} \text {, }
$$

$\mathrm{K}_{\mathrm{t}+1}$ and the Lagrangean multiplier $\lambda_{\mathrm{t}}$, and then by eliminating $\lambda_{\mathrm{t}}$, thus obtaining:

replaces interpersonal trust. However, constructing and preserving effective public institutions are themselves collective action problems that cannot be solved without some diffuse trust among citizens (see Rothstein, 2000). 


$$
\begin{gathered}
\frac{\mathrm{W}_{\mathrm{t}}}{\mathrm{C}_{\mathrm{t}}}=\frac{\gamma}{\left(1-\mathrm{L}_{\mathrm{t}}\right)}, \\
\mathrm{C}_{\mathrm{t}+1}=\theta \mathrm{C}_{\mathrm{t}}\left(1-\delta+\mathrm{R}_{\mathrm{t}+1}\right), \\
\mathrm{K}_{\mathrm{t}+1}=(1-\delta) \mathrm{K}_{\mathrm{t}}+\pi_{\mathrm{t}}+\mathrm{W}_{\mathrm{t}} \mathrm{L}_{\mathrm{t}}+\mathrm{R}_{\mathrm{t}} \mathrm{K}_{\mathrm{t}}-\mathrm{C}_{\mathrm{t}} .
\end{gathered}
$$

By using (A1)-(A4) and (A7), one can derive (13) from (A8) and (14) from (A9).

Finally, by eliminating $\lambda_{t}$, the transversality condition that an optimal path must satisfy is:

$$
\lim _{t \rightarrow \infty} \theta^{t} \frac{K_{t}}{C_{t}}=0
$$

By using (A1)-(A3) and (A7), (A10) can be rewritten as in (15).

\section{Numerical example showing the existence of multiple BGPS}

Let $\zeta=0.9523809 ; \alpha=0.6 ; \beta=0.3 ; \delta=0.09 ; \gamma=0.5897538 ; \theta=0.9852931 ; \rho=1.3315564 ; \xi=0.01$. Given these parameter values, there exist two BGPs characterized, respectively, by $\left(\mathrm{Q}^{\circ}, \mathrm{V}^{\circ}\right)$ and by $\left(\mathrm{Q}^{*}, \mathrm{~V}^{*}\right)$, where $\mathrm{Q}^{\circ} \approx 0 ; \mathrm{V}^{\circ} \approx 0.05619$; $\mathrm{L}^{\circ} \approx 0.6182 ; \mathrm{h}^{\circ} \approx 0.0627 ; \mathrm{Q}^{*} \approx 1.18 ; \mathrm{V}^{*} \approx 0.025 ; \mathrm{L}^{*} \approx 0.5982555 ; \mathrm{h}^{*} \approx 0.0584367$

\section{Proof of Proposition 1}

Considering equations (13) and (14), one has that along a BGP both these equations must hold:

$$
\eta(\mathrm{Q}, \mathrm{V})=1-\delta-\mathrm{V}+\frac{\mathrm{V}\left(\mathrm{Q}^{1 / \zeta}+1\right)}{1-\alpha-\beta}\left\{1-\frac{\alpha}{\gamma}\left[\frac{(1-\alpha-\beta) \mathrm{V}^{(1-\alpha-\beta)(1-\zeta)}}{\mathrm{V}\left(\mathrm{Q}^{1 / \zeta}+1\right)^{1-\zeta(1-\alpha-\beta)}}\right]^{1 / \alpha}+\frac{\alpha}{\gamma}\right\}-\theta\left[1-\delta+\frac{\beta \mathrm{V}\left(\mathrm{Q}^{1 / \zeta}+1\right)}{1-\alpha-\beta}\right]=0
$$

and $\mathrm{h}=\theta\left[1-\delta+\frac{\beta \mathrm{M}}{1-\alpha-\beta}\right], \mathrm{M} \equiv \mathrm{V}\left(\mathrm{Q}^{1 / \zeta}+1\right)$, where

$$
\begin{gathered}
\frac{d \mathrm{~V}}{d \mathrm{Q}} \mid \eta(\mathrm{Q}, \mathrm{V})=0<0, \\
\frac{d \mathrm{~h}}{d \mathrm{M}}>0 .
\end{gathered}
$$

Note that equation (A11) can also be written as

$$
\begin{array}{r}
v(\mathrm{M}, \mathrm{V})=1-\delta-\mathrm{V}+\frac{\mathrm{M}}{1-\alpha-\beta}\left\{1-\frac{\alpha}{\gamma}\left[\frac{(1-\alpha-\beta) \mathrm{V}^{(1-\alpha-\beta)(1-\zeta)}}{\mathrm{M}^{1-\zeta(1-\alpha-\beta)}}\right]^{1 / \alpha}+\frac{\alpha}{\gamma}\right\}-\theta\left[1-\delta+\frac{\beta \mathrm{M}}{1-\alpha-\beta}\right]=0, \quad \text { where } \\
\left.\frac{d \mathrm{M}}{d \mathrm{~V}}\right|_{v(\mathrm{M}, \mathrm{V})=0}>0 .
\end{array}
$$


Given (A12)-(A14), it is straightforward that a lower Q entails a higher h.

To verify that a higher $\mathrm{h}$ entails a higher $\mathrm{g}, \mathrm{g}_{\mathrm{t}} \equiv \frac{\mathrm{GDP}_{\mathrm{t}+1}-\mathrm{GDP}_{\mathrm{t}}}{\mathrm{GDP}_{\mathrm{t}}}$, consider that along a BGP $\mathrm{h}=\mathrm{g}$. In its turn, this can be verified by considering that (A6) can be rewritten as $\operatorname{GDP}_{t}=X_{t}\left(Q_{t}^{\frac{1}{\zeta}}+\alpha+\beta\right)(1-\alpha-\beta)^{-1}$, and that along a BGP one has $\mathrm{Q}_{\mathrm{t}+1}=\mathrm{Q}_{\mathrm{t}}=\mathrm{Q}$ and $\mathrm{V}_{\mathrm{t}+1}=\mathrm{V}_{\mathrm{t}}=\mathrm{V}$, thus entailing $\mathrm{h}=\mathrm{g}$.

4. Derivation of the system of equations governing the equilibrium path of the economy in the special case in which $\zeta=1$ If $\zeta=1$, one can obtain the following equations from the maximization of (4) with respect to $\mathrm{X}_{\mathrm{t}}, \mathrm{L}_{\mathrm{t}}$, and $\mathrm{K}_{\mathrm{t}}$ :

$$
\begin{gathered}
\mathrm{X}_{\mathrm{t}}=\mathrm{L}_{\mathrm{t}}^{\frac{\alpha}{\alpha+\beta}}(1-\alpha-\beta)^{\frac{1}{\alpha+\beta}} \mathrm{K}_{\mathrm{t}}-\mathrm{S}_{\mathrm{t}} \\
\mathrm{W}_{\mathrm{t}}=\mathrm{L}_{\mathrm{t}}^{\frac{\alpha}{\alpha+\beta}-1} \alpha(1-\alpha-\beta)^{\frac{1-\alpha-\beta}{\alpha+\beta}} \mathrm{K}_{\mathrm{t}}, \\
\mathrm{R}_{\mathrm{t}}=\mathrm{L}_{\mathrm{t}}^{\frac{\alpha}{\alpha+\beta}} \beta(1-\alpha-\beta)^{\frac{1-\alpha-\beta}{\alpha+\beta}}
\end{gathered}
$$

Given (1), (2), (4) and (A15)-(A17), one has:

$$
\begin{gathered}
\pi_{\mathrm{t}}=\mathrm{S}_{\mathrm{t}} \\
\mathrm{Y}_{\mathrm{t}}=\mathrm{L}_{\mathrm{t}}^{\frac{\alpha}{\alpha+\beta}}(1-\alpha-\beta)^{\frac{1-\alpha-\beta}{\alpha+\beta}} \mathrm{K}_{\mathrm{t}},
\end{gathered}
$$

By using (5), (A7)-(A9) and (A15)-(A19), one can derive

$$
\begin{aligned}
& \phi\left(\mathrm{D}_{\mathrm{t}+1}, \mathrm{D}_{\mathrm{t}}, \mathrm{L}_{\mathrm{t}}\right)=\mathrm{D}_{\mathrm{t}+1}\left[1+\mu\left(\mathrm{L}_{\mathrm{t}}, \mathrm{D}_{\mathrm{t}}\right)\right]-\mathrm{D}_{\mathrm{t}}-\mathrm{D}_{\mathrm{t}} \rho\left[\frac{\mathrm{D}_{\mathrm{t}}}{\mathrm{L}_{\mathrm{t}}^{\frac{\alpha}{\alpha+\beta}}(1-\alpha-\beta)^{\frac{1-\alpha-\beta}{\alpha+\beta}}}-\xi\right]=0 \\
& \psi\left(\mathrm{L}_{\mathrm{t}+1}, \mathrm{D}_{\mathrm{t}}, \mathrm{L}_{\mathrm{t}}\right)=Z\left(\mathrm{~L}_{\mathrm{t}+1}\right)\left[1+\mu\left(\mathrm{L}_{\mathrm{t}}, \mathrm{D}_{\mathrm{t}}\right)\right]-Z\left(\mathrm{~L}_{\mathrm{t}}\right) \theta\left[1-\delta+\beta \mathrm{L}_{\mathrm{t}+1}^{\frac{\alpha}{\alpha+\beta}}(1-\alpha-\beta)^{\frac{1-\alpha-\beta}{\alpha+\beta}}\right]=0
\end{aligned}
$$

where

$$
\begin{gathered}
\mathrm{h}_{\mathrm{t}}=\mu\left(\mathrm{L}_{\mathrm{t}}, \mathrm{D}_{\mathrm{t}}\right)=\mathrm{D}_{\mathrm{t}}-\delta-Z\left(\mathrm{~L}_{\mathrm{t}}\right)+(\alpha+\beta) \mathrm{L}_{\mathrm{t}}^{\frac{\alpha}{\alpha+\beta}}(1-\alpha-\beta)^{\frac{1-\alpha-\beta}{\alpha+\beta}}, \\
\mathrm{Z}_{\mathrm{t}} \equiv \frac{\mathrm{C}_{\mathrm{t}}}{\mathrm{K}_{\mathrm{t}}}=Z\left(\mathrm{~L}_{\mathrm{t}}\right)=\frac{\alpha\left(1-\mathrm{L}_{\mathrm{t}}\right) \mathrm{L}_{\mathrm{t}}^{\frac{-\beta}{\alpha+\beta}}(1-\alpha-\beta)^{\frac{1-\alpha-\beta}{\alpha+\beta}}}{\gamma} .
\end{gathered}
$$

Together with (A20)-(A23), an equilibrium path must satisfy the transversality condition 


$$
\lim _{t \rightarrow \infty} \theta^{t}\left[Z\left(L_{t}\right)\right]^{-1}=0
$$

5. Proof that if $\zeta=1$ there may exist at most two $B G P,\left(L^{\circ}, D^{\circ}\right)$ and $\left(L^{*}, D^{*}\right)$, where $L^{\circ}>L^{*}$ and $D^{\circ}=0<D^{*}$

Considering (A20)-(A23), one has that $\mathrm{D}^{\circ}$ and $\mathrm{L}^{\circ}$ are those values of $\mathrm{D}$ and $\mathrm{L}$ which satisfy, respectively, $\mathrm{D}=0$ and

$$
\left.f(\mathrm{~L})=1-\delta-Z(\mathrm{~L})+(\alpha+\beta) \mathrm{L}^{\frac{\alpha}{\alpha+\beta}}(1-\alpha-\beta)^{\frac{1-\alpha-\beta}{\alpha+\beta}}\right]-\theta\left[1-\delta+\beta \mathrm{L}^{\frac{\alpha}{\alpha+\beta}}(1-\alpha-\beta)^{\frac{1-\alpha-\beta}{\alpha+\beta}}\right]=0 .
$$

Since $\frac{d f(\mathrm{~L})}{d \mathrm{~L}}>0,0 \leq \mathrm{L} \leq 1$, it is apparent that only one value of $\mathrm{L}, \mathrm{L}=\mathrm{L}^{\circ}$, can satisfy (A25).

Again, considering (A20)-(A23), one has that $\mathrm{L}^{*}$ and $\mathrm{D*}$ are those values of $\mathrm{L}$ and $\mathrm{D}$ which satisfy both

$$
\left.h(\mathrm{~L})=1-\delta-Z(\mathrm{~L})+D(\mathrm{~L})+(\alpha+\beta) \mathrm{L}^{\frac{\alpha}{\alpha+\beta}}(1-\alpha-\beta)^{\frac{1-\alpha-\beta}{\alpha+\beta}}\right]-\theta\left[1-\delta+\beta \mathrm{L}^{\frac{\alpha}{\alpha+\beta}}(1-\alpha-\beta)^{\frac{1-\alpha-\beta}{\alpha+\beta}}\right]=0
$$

and

$$
\mathrm{D}=D(\mathrm{~L})=\mathrm{L}^{\frac{\alpha}{\alpha+\beta}}(1-\alpha-\beta)^{\frac{1-\alpha-\beta}{\alpha+\beta}}\left\{\frac{\theta}{\rho}\left[1-\delta+\beta \mathrm{L}^{\frac{\alpha}{\alpha+\beta}}(1-\alpha-\beta)^{\frac{1-\alpha-\beta}{\alpha+\beta}}\right]-\frac{1}{\rho}+\xi\right\}>0 .
$$

Since $\frac{d D(\mathrm{~L})}{d \mathrm{~L}}>0$ and $\frac{d h(\mathrm{~L})}{d \mathrm{~L}}>0,0 \leq \mathrm{L} \leq 1$, it is apparent that only one pair of values of $\mathrm{L}$ and $\mathrm{D}, \mathrm{L}=\mathrm{L}^{*}$ and $\mathrm{D}=\mathrm{D}^{*}$, can satisfy (A26)-(A27).

Finally, one can verify by comparing (A25) and (A26)--and by considering that $\frac{d f(\mathrm{~L})}{d \mathrm{~L}}>0$--that the value of $\mathrm{L}$ satisfying (A11), $\mathrm{L}=\mathrm{L}^{\circ}$, must be strictly greater than the value of $\mathrm{L}$ satisfying (A26), $\mathrm{L}=\mathrm{L}^{*}$.

6. Numerical example showing that in the case in which $\zeta=1$ there exist $\left(L^{\circ}, D^{\circ}\right)$ and $\left(L^{*}, D^{*}\right)$, where $g^{\circ}>0$.

Let $\zeta=1 ; \alpha=0.6 ; \beta=0.3 ; \delta=0.09 ; \gamma=0.5238455 ; \theta=0.9441046 ; \rho=0.288516 ; \xi=0.002$. Given these parameter values, one has two BGPs characterized, respectively, by $\left(\mathrm{L}^{\circ}, \mathrm{D}^{\circ}\right)$ and by $\left(\mathrm{L}^{*}, \mathrm{D}^{*}\right)$, where $\mathrm{L}^{\circ} \approx 0.6182 ; \mathrm{D}^{\circ} \approx 0 ; \mathrm{h}^{\circ}=\mathrm{g}^{\circ} \approx 0.01828$; $\mathrm{L}^{*} \approx 0.60 ; \mathrm{D}^{*} \approx 0.03 ; \mathrm{h}^{*}=\mathrm{g}^{*} \approx 0.015137$

\section{Proof of Proposition 2}

By considering (A21), one can easily check that along a BGP the growth rate of $\mathrm{K}_{\mathrm{t}}$ is given by

$\mathrm{h}=\theta\left[1-\delta+\beta \mathrm{L}^{\frac{\alpha}{\alpha+\beta}}(1-\alpha-\beta)^{\frac{1-\alpha-\beta}{\alpha+\beta}}\right]-1$, which is strictly increasing in L. Hence, since $\mathrm{L}^{\circ}>\mathrm{L}^{*}$, one must have $\mathrm{h}^{\circ}>\mathrm{h}^{*}$, thus entailing $\mathrm{g}^{\circ}>\mathrm{g}^{*}$. 


\section{Proof of Proposition 3}

To verify that $\left(\mathrm{L}^{\circ}, \mathrm{D}^{\circ}\right)$ is saddle-path stable and $\left(\mathrm{L}^{*}, \mathrm{D}^{*}\right)$ is unstable, consider that the characteristic equation of the system obtained by linearizing (A20)-(A21) around (L,D) is

$$
\chi^{2}+\left[\frac{\phi_{\mathrm{D}_{\mathrm{t}}}}{\phi_{\mathrm{D}_{\mathrm{t}+1}}}+\frac{\psi_{\mathrm{L}_{\mathrm{t}}}}{\psi_{\mathrm{L}_{\mathrm{t}+1}}}\right] \chi+\frac{\phi_{\mathrm{D}_{\mathrm{t}}} \psi_{\mathrm{L}_{\mathrm{t}}}}{\phi_{\mathrm{D}_{\mathrm{t}+1}} \psi_{\mathrm{L}_{\mathrm{t}+1}}}-\frac{\phi_{\mathrm{L}_{\mathrm{t}}} \psi_{\mathrm{D}_{\mathrm{t}}}}{\phi_{\mathrm{D}_{\mathrm{t}+1}} \psi_{\mathrm{L}_{\mathrm{t}+1}}}=0,
$$

where $\chi_{1}$ and $\chi_{2}$ are the characteristic roots, $\left[\frac{\phi_{\mathrm{D}_{\mathrm{t}}}}{\phi_{\mathrm{D}_{\mathrm{t}+1}}}+\frac{\psi_{\mathrm{L}_{\mathrm{t}}}}{\psi_{\mathrm{L}_{\mathrm{t}+1}}}\right]<-2, \frac{\phi_{\mathrm{D}_{\mathrm{t}}} \psi_{\mathrm{L}_{\mathrm{t}}}}{\phi_{\mathrm{D}_{\mathrm{t}+1}} \psi_{\mathrm{L}_{\mathrm{t}+1}}}-\frac{\phi_{\mathrm{L}_{\mathrm{t}}} \psi_{\mathrm{D}_{\mathrm{t}}}}{\phi_{\mathrm{D}_{\mathrm{t}+1}} \psi_{\mathrm{L}_{\mathrm{t}+1}}}>1$ and all derivatives are evaluated at $(\mathrm{L}, \mathrm{D})$.

Given (A28), one has that (L,D) is $\left\{\begin{array}{l}\text { saddle-path stable }\left(0<\chi_{1}<1, \chi_{2}>1\right) \\ \text { unstable }\left(\chi_{1}>1, \chi_{2}>1\right)\end{array}\right\}$ whenever

$$
1+\left[\frac{\phi_{\mathrm{D}_{\mathrm{t}}}}{\phi_{\mathrm{D}_{\mathrm{t}+1}}}+\frac{\psi_{\mathrm{L}_{\mathrm{t}}}}{\psi_{\mathrm{L}_{\mathrm{t}+1}}}\right]+\frac{\phi_{\mathrm{D}_{\mathrm{t}}} \psi_{\mathrm{L}_{\mathrm{t}}}}{\phi_{\mathrm{D}_{\mathrm{t}+1}} \psi_{\mathrm{L}_{\mathrm{t}+1}}}-\frac{\phi_{\mathrm{L}_{\mathrm{t}}} \psi_{\mathrm{D}_{\mathrm{t}}}}{\phi_{\mathrm{D}_{\mathrm{t}+1}} \psi_{\mathrm{L}_{\mathrm{t}+1}}}\{<\}<,
$$

where $\phi_{\mathrm{D}_{\mathrm{t}+1}} \psi_{\mathrm{L}_{\mathrm{t}+1}}<0$. Moreover, one can check that

$$
\frac{-\left(\phi_{\mathrm{D}_{\mathrm{t}}}+\phi_{\mathrm{D}_{\mathrm{t}+1}}\right)}{\phi_{\mathrm{L}_{\mathrm{t}}}}\left\{\begin{array}{l}
< \\
>
\end{array}\right\} \frac{-\psi_{\mathrm{D}_{\mathrm{t}}}}{\psi_{\mathrm{L}_{\mathrm{t}}}+\psi_{\mathrm{L}_{\mathrm{t}+1}}} \text { at }\left\{\begin{array}{l}
\left(\mathrm{L}^{\circ}, \mathrm{D}^{\circ}\right) \\
\left(\mathrm{L}^{*}, \mathrm{D}^{*}\right)
\end{array}\right\},
$$

where $\phi_{\mathrm{L}_{\mathrm{t}}}>0$ and $\psi_{\mathrm{L}_{\mathrm{t}}}+\psi_{\mathrm{L}_{\mathrm{t}+1}}>0$, which implies

$$
1+\left[\frac{\phi_{\mathrm{D}_{\mathrm{t}}}}{\phi_{\mathrm{D}_{\mathrm{t}+1}}}+\frac{\psi_{\mathrm{L}_{\mathrm{t}}}}{\psi_{\mathrm{L}_{\mathrm{t}+1}}}\right]+\frac{\phi_{\mathrm{D}_{\mathrm{t}}} \psi_{\mathrm{L}_{\mathrm{t}}}}{\phi_{\mathrm{D}_{\mathrm{t}+1}} \psi_{\mathrm{L}_{\mathrm{t}+1}}}-\frac{\phi_{\mathrm{L}_{\mathrm{t}}} \psi_{\mathrm{D}_{\mathrm{t}}}}{\phi_{\mathrm{D}_{\mathrm{t}+1}} \psi_{\mathrm{L}_{\mathrm{t}+1}}}\left\{>0 \text { at }\left\{\begin{array}{l}
\left(\mathrm{L}^{\circ}, \mathrm{D}^{\circ}\right) \\
\left(\mathrm{L}^{*}, \mathrm{D}^{*}\right)
\end{array}\right\}\right. \text {. }
$$

Hence, $\left(\mathrm{L}^{\circ}, \mathrm{D}^{\circ}\right)$ is saddle-path stable and $\left(\mathrm{L}^{*}, \mathrm{D}^{*}\right)$ is unstable.

\section{Proof of Proposition 4}

To find the eigenvectors associated with the system (A20)-(A21) linearized in a neighborhood of $\left(\mathrm{L}^{*}, \mathrm{D}^{*}\right)$, one must

solve $\left[\begin{array}{cc}\frac{-\phi_{D_{t}}}{\phi_{D_{t+1}}} & \frac{-\phi_{L_{t}}}{\phi_{D_{t+1}}} \\ \frac{-\psi_{D_{t}}}{\psi_{L_{t+1}}} & \frac{-\psi_{L_{t}}}{\psi_{L_{t+1}}}\end{array}\right]\left[\begin{array}{ll}\mathrm{e}_{11} & \mathrm{e}_{12} \\ \mathrm{e}_{21} & \mathrm{e}_{22}\end{array}\right]=\left[\begin{array}{ll}\mathrm{e}_{11} & \mathrm{e}_{12} \\ \mathrm{e}_{21} & \mathrm{e}_{22}\end{array}\right]\left[\begin{array}{ll}\chi_{1} & 0 \\ 0 & \chi_{2}\end{array}\right]$, thus obtaining $\mathrm{e}_{11}=1$ and $\mathrm{e}_{21}=\frac{\frac{-\psi_{\mathrm{D}_{\mathrm{t}}}}{\psi_{\mathrm{L}_{\mathrm{t}+1}}}}{\chi_{1}+\frac{\psi_{\mathrm{L}_{\mathrm{t}}}}{\psi_{\mathrm{L}_{\mathrm{t}+1}}}}$, where

$0<\chi_{1}<1, \frac{-\psi_{\mathrm{D}_{\mathrm{t}}}}{\psi_{\mathrm{L}_{\mathrm{t}+1}}}>0$ and $\frac{\psi_{\mathrm{L}_{\mathrm{t}}}}{\psi_{\mathrm{L}_{\mathrm{t}+1}}}<-1$, which entails $\mathrm{e}_{21}<0$. 


\section{Acknowledgements}

The authors thank two anonymous referees of the JEBO for their useful comments that helped us to improve the quality of the paper.

\section{References}

Aghion, P., Howitt, P., 1998. Endogenous Growth Theory, Cambridge: MIT Press.

Barro, R.J., Sala-i-Martin, X., 1995. Economic Growth, New York: McGraw-Hill.

Bartolini, S., Bilancini, E., 2006. Does a decline in social capital depress labor hours?. University of Siena, Department of Economics, mimeo.

Beugelsdijk, S., de Groot., H.L.F, van Schaik, T., 2004. Trust and economic growth: a robustness analysis. Oxford Economic Papers 56, 118-134.

Beugelsdijk, S., Smulders, S., 2004. Social capital and economic growth. Tilburg University, Department of Economics, mimeo.

Beugelsdijk, S., van Schaik, T., 2005. Social capital and growth in European regions: An empirical test. European Journal of Political Economy 21, 301-324.

Bjørnskov, C., 2004. Trust and the growth of schooling. Aarhus School of Business, mimeo.

Bourdieu, P., 1986. Forms of capital. In: Richardson, J.G. (Ed.). Handbook of Theory and Research for the Sociology of Education. New York: Greenwood Press, 241-258.

Bovenberg, A.L., 2003. Unity produces diversity: The economics of Europe's social capital. In: W. Arts, W., Hagennars, J., Halman, L. (Eds.). The Cultural Diversity of European Unity, Leiden, Boston: Brill, 403-419.

Bowles, S., Gintis, H., 1976. Schooling in Capitalist America. London: Routledge and Kegan.

Bowles, S., Gintis, H., 2002. Social capital and community governance. The Economic Journal 112, F419-F436.

Bowles, S., Jayadev, A., 2006. Guard labor. Journal of Development Economics 79, 328-348. 
Casey, T., Christ, K., 2002. Social capital and economic performance in the American states. Paper presented at the 2002 American Political Science Association Conference, Boston.

Chou, Y.K., 2002. Modelling social capital and growth. Research Paper No. 865, University of Melbourne, Department of Economics.

Coleman, J., 1988. Social capital in the creation of human capital. American Journal of Sociology 94, S95-S120.

Costa, D.L., Kahn, M.E., 2003. Understanding the American decline in social capital. Kyklos 56, $17-46$.

Denzau, A.T., North, D.C., 1994. Shared mental models: Ideologies and institutions. Kyklos 47, 331.

Durlauf, S.N., 2002a. On the empirics of social capital. The Economic Journal 112, F439-F479.

Durlauf, S.N., 2002b. Bowling alone: A review essay. Journal of Economic Behavior \& Organization 47, 259-273.

Durlauf, S.N., Fafchamps, M., 2004. Social capital. NBER Working Paper Series, No.10485, National Bureau of Economic Research.

Frankel, M., 1962. The production function in allocation and growth: A synthesis. American Economic Review 52, 995-1022.

Freeman, R.B., Schettkat, R., 2005. Marketization of household production and the EU-US gap in work. Economic Policy 20, No. 41, 6-50.

Fukuyama, F., 1995. Trust-The Social Virtues and the Creation of Prosperity. New York: Free Press.

Hardin, R., 1998. Trust in government. In: Braithwaite, V., Levi, M. (Eds.). Trust and Governance. New York: Russell Sage Foundation, 9-27.

Heyer, J., Stewart, F., Thorp, R. (Eds.), 2002. Group Behavior and Development: Is the Market Destroying Cooperation?. Oxford: Oxford University Press.

Hirschman, A.O., 1982. Rival interpretations of market society: civilizing, destructive or 
feeble?. Journal of Economic Literature 20, 1463-1484.

Hirsch, F., 1976. Social Limits to Growth. Cambridge: Harvard University Press.

Keele, L., 2004. Macro measures and mechanics of social capital. Department of Politics and International Relations, Nuffield College and Oxford University, mimeo.

Knack, S., Keefer, P., 1997. Does social capital have an economic impact? A cross-country investigation. Quarterly Journal of Economics 112, 1251-1288.

Kolodinsky, J., Kimberly, G., Isham, J., 2003. The effects of volunteering for non-profit organizations on social capital formation: Evidence from a statewide survey. Discussion Paper No. 03-05, Middlebury College of Economics.

Ladd, E., 1996. The data just don't show erosion of America's social capital. Public Perspective, 4-22.

La Porta, R., Lopez-de-Silanes, F., Schleifer, A., Vishny, R.W., 1997. Trust in large organizations. American Economic Review Papers and Proceedings 87, 333-338.

Levi, M., 1998. A state of trust. In: Braithwaite, V., Levi, M. (Eds.). Trust and Governance. New York: Russell Sage Foundation, 77-101.

Maskell, P., 2000. Social capital, innovation, and competitiveness. In: Baron, S., Field, J., Schuller, T. (Eds.). Social Capital: Critical Perspectives. New York: Oxford University Press, 111123.

Miguel, E., Gertler, P., Levine, D.I., 2006. Does industrialization build or destroy social networks?. Economic Development and Cultural Change 54, 287-317.

Paxton, P., 1999. Is social capital declining? A multiple indicator assessment. American Journal of Sociology 105, 88-127.

Piazza-Georgi, B., 2002. The role of human and social capital in growth: extending our knowledge. Cambridge Journal of Economics 26, 461-479.

Putnam, R.D., 1995. Bowling alone: America's declining social capital. Journal of Democracy $6,65-78$. 
Putnam, R.D., 2000. Bowling Alone: The Collapse and Revival of American Community.

New York: Simon\&Schuster.

Rothstein, B., 2000. Trust, social dilemmas, and the strategic construction of collective memories. Journal of Theoretical Politics 12, 477-501.

Routledge, B.R., von Amsbergh, J., 2003. Social capital and growth. Journal of Monetary Economics 50, 167-193.

Rupasingha, A., Goetz, S.J., Freshwater, D., 2002. Social and institutional factors as determinants of economic growth: Evidence from the United States counties. Papers in Regional Science 81, 139-155.

Schneider, M., Teske, P., Marshall, M., Mintrom, M., Roch, C., 1997. Institutional arrangements and the creation of social capital: The effects of public school choice. American Political Science Review 91, 2-93.

Skocpol, T., 1999. Associations without members. American Prospect 45, 66-73.

Wallis, J.J., North, D.C., 1986. Measuring the transaction sector in the American economy, 18701970. In: Engerman, S.L., Gallman, R.E. (eds.). Long-Term Factors in American Economic Growth. Chicago: Chicago University Press, 95-148.

Zak, P.J., Knack, S., 2001. Trust and growth. The Economic Journal 111, 295-321. 